\title{
Dietary Lignans: Definition, Description and Research Trends in Databases Development
}

\author{
Alessandra Durazzo ${ }^{1, *}$, Massimo Lucarini ${ }^{1}$, Emanuela Camilli ${ }^{1}$, Stefania Marconi ${ }^{1}$, \\ Paolo Gabrielli ${ }^{1}$, Silvia Lisciani ${ }^{1}$ (D), Loretta Gambelli ${ }^{1}$, Altero Aguzzi ${ }^{1}$, Ettore Novellino ${ }^{2}$, \\ Antonello Santini ${ }^{2}$, Aida Turrini ${ }^{1}$ and Luisa Marletta ${ }^{1}$ (D) \\ 1 CREA Research Centre for Food and Nutrition, Via Ardeatina 546, 00178 Rome, Italy; \\ massimo.lucarini@crea.gov.it (M.L.); emanuela.camilli@crea.gov.it (E.C.); stefania.marconi@crea.gov.it (S.M.); \\ paolo.gabrielli@crea.gov.it (P.G.); silvia.lisciani@crea.gov.it (S.L.); loretta.gambelli@crea.gov.it (L.G.); \\ altero.aguzzi@crea.gov.it (A.A.); aida.turrini@crea.gov.it (A.T.); luisa.marletta@crea.gov.it (L.M.) \\ 2 Department of Pharmacy, University of Napoli Federico II, Via D. Montesano 49, 80131 Napoli, Italy; \\ ettore.novellino@unina.it (E.N.); asantini@unina.it (A.S.) \\ * Correspondence: alessandra.durazzo@crea.gov.it; Tel.: +30-065-149-4430
}

Received: 9 November 2018; Accepted: 6 December 2018; Published: 8 December 2018

\begin{abstract}
The study aims to communicate the current status regarding the development and management of the databases on dietary lignans; within the phytochemicals, the class of the lignan compounds is of increasing interest because of their potential beneficial properties, i.e., anticancerogenic, antioxidant, estrogenic, and antiestrogenic activities. Furthermore, an introductory overview of the main characteristics of the lignans is described here. In addition to the importance of the general databases, the role and function of a food composition database is explained. The occurrence of lignans in food groups is described; the initial construction of the first lignan databases and their inclusion in harmonized databases at national and/or European level is presented. In this context, some examples of utilization of specific databases to evaluate the intake of lignans are reported and described.
\end{abstract}

Keywords: dietary lignans; national databases; food groups; dietary intake; harmonized databases

\section{Introduction}

Within phytochemicals, phenolic compounds called lignans have attracted the interest of food chemists and nutrition researchers over the years. Lignans are vascular plant secondary metabolites, with widespread occurrence in the plant kingdom, and which are ascribed a wide range of physiological functions, positively affecting human health [1]. They are a class of secondary plant metabolites that belong to the group of diphenolic compounds derived from the combination of two phenylpropanoid C6-C3 units at the $\beta$ and $\beta^{\prime}$ carbon, and can be linked to additional ether, lactone, or carbon bonds; they have a chemical structure like the 1,4-diarylbutan [2]. The range of their structures and biological activities is broad. They are derived from the shikimic acid biosynthetic pathway [3]. The range relative to structurally different forms of lignans and biological activities is broad [4,5]. The main commonly studied and reported compounds are secoisolariciresinol, lariciresinol, matairesinol, pinoresinol, medioresinol, and syringaresinol (shown in Figure 1), while, recently, the isolation and structure elucidation of new lignan compounds have been carried out [6-8] and the spectrum of their attributing properties has been widened [9-11]. 
<smiles>COc1cc(CC(CO)C(CO)Cc2ccc(O)c(OC)c2)ccc1O</smiles>

(a) secoisolariciresinol<smiles>COc1cc(CC2COC(c3ccc(O)c(OC)c3)C2CO)ccc1O</smiles>

(c) lariciresinol<smiles>COc1cc(C2OCC3C(c4cc(OC)c(O)c(OC)c4)OCC23)ccc1O</smiles>

(e) medioresinol<smiles>COc1cc(CC2COC(=O)C2Cc2ccc(O)c(OC)c2)ccc1O</smiles>

(b) matairesinol<smiles>COc1cc(C2OCC3C(c4ccc(O)c(OC)c4)OCC23)ccc1O</smiles>

(d) pinoresinol<smiles>COc1cc(C2OCC3C(c4cc(OC)c(O)c(OC)c4)OCC23)cc(OC)c1O</smiles>

(f) syringaresinol

Figure 1. The chemical structure of main dietary lignans, (a) secoisolariciresinol, (b) matairesinol, (c) lariciresinol, (d) pinoresinol, (e) medioresinol, and (f) syringaresinol.

Plant lignans give rise to metabolites, enterodiol, and enterolactone [12], generally called enterolignans due to their colonic origin (named also mammalian lignans) (shown in Figure 2). 
<smiles>OCC(CO)C(CO)Cc1cccc(O)c1</smiles>

(a) enterodiol<smiles>O=C1OCC(Cc2cccc(O)c2)C1Cc1cccc(O)c1</smiles>

(b) enterolactone

Figure 2. The chemical structure of enterolignans, (a) enterodiol and (b) enterolactone.

Enterolignans, and some of their plant precursors, are reported to have several biological activities-antitumorigenic [13], anticarcinogenic [14], estrogenic or anti-estrogenic [15,16], as well as antioxidant properties [17].

Lignans, in line with other natural compounds, contribute in disease prevention and health promotion [18,19]; several studies have showed the potential of lignan-rich diets against the development of various diseases, particularly hormone-dependent cancer, cardiovascular diseases, and diabetes [20-27].

Lignans are the basis for novel perspectives for health promotion and disease prevention as nutraceuticals and functional foods [28-32]. Currently, Pilkington, [33], by using a chemometric approach, have analyzed the physicochemical properties of classical lignans, neolignans, flavonolignans, and carbohydrate-lignan conjugates to assess their absorption, distribution, metabolism, excretion and toxic (ADMET) profiles, and establish if these compounds are lead-like/drug-like and, thus, have potential to be, or act as, a driver in the development of future therapeutics; the results showed how carbohydrate-lignan conjugates and flavonolignans are less drug-like, while lignans showed a particularly high level of drug-likeness [33].

Nowadays, lignan species and their quantity in food products are determined. Different methodologies have been defined for the extraction and identification of lignans [34-40]. The extraction procedure from the food matrix represents a key issue and, in particular, the type of hydrolysis step (alkaline, acid hydrolysis, enzymatic hydrolysis, or a mixture of them). The expanding demand for lignans are stimulating the interest in identification of new sources and in improvement of analytical and purification procedures. Analytical values using HPLC, as well as either gas or liquid chromatography-mass spectrometry, were developed and carried out [41,42]. The development and the assessment of methodologies for the extraction, identification, and determination of lignans are achieved $[17,43,44]$. Also, the "new" emerging lignans, due to LC combined with HR-MS/MS, have been, and will continue, broadening the view regarding dietary lignans [45]; simultaneously, the synthesis [46,47] and the design [48] of new compounds are being carried out.

The complex relationship between food, nutrition, and health [49] is explored via nutrients and bioactive compounds, i.e., beneficial food components [50], and via non-beneficial food components [51]. In this direction, a directory of information about bioactive component databases, specialized, at a national and European level, is being developed, and will be useful for the planning and evaluation of clinical and epidemiological research studies on bioactive components. Databases of lignans in food products are being creating in several countries (Finland, Netherlands, United States, Canada, United Kingdom, Japan, and Spain), and represent the first step for establishing comprehensive and harmonized dietary databases, including all or nearly all bioactive compounds [1]. Reliable methods of exposure measurement are essential for understanding the potential benefits of lignans [52]. 


\section{Databases: Significance, Principles and Common Criteria/Measures}

Databases, also called electronic databases, represent a system to generate and collect any data, information, and documentation specially organized for rapid search and retrieval by a computer [53]. Databases are tools constructed to facilitate the storage, retrieval, modification, and deletion of data in conjunction with various data-processing operations [54].

A comprehensive food composition database (FCDB) should be a repository of all numeric, descriptive, and graphical information on the nutrient characteristics of foods [55]; the term food composition data indicates all information referring to the description and identification of foods and their food components (nutrient values, number of sample collections and analyses, analytical methods, descriptive coding, photos, data source, value documentation, etc.) and include various steps in the production, generation, compilation, and publication of data [55].

The EuroFIR project (European Food Information Resource Network of Excellence) was born to develop and integrate a comprehensive, coherent, and validated network of databanks providing a single, authoritative source of food composition data for Europe [56,57]. In this project, efforts in developing procedures for defining and establishing a standardized approach of study have been carried out from the various European partners within their FCDB [56,57].

The establishment of the "Project Committee-Food composition data" (CEN/TC 387, 2008-2013) [58] was an important milestone for the EuroFIR Network of Excellence to reach this objective. A common European standard, established within the CEN-European Committee for Standardization framework, represents a key tool enabling unambiguous identification and description of food composition data and its quality in e.g. databases, for dissemination and interchange [58].

Generally, the use of database management system allows the administration of large volumes of information and data by providing epidemiological research to store large varieties of food consumed for each individual subject and the comparability of data, representing a basic tool for obtaining reliable information on the relationship between nutrients and foods $[59,60]$.

The utilization made by different users requires that FCDBs follow very specific compilation criteria, such as representativeness, accuracy in the production and selection of analytical values, traceability of data taken from other sources at the nutrient level, and clarity in the designation and description of the food [60].

In this context, the food grouping systems in food composition databases represent a key tool. Currently, Durazzo et al. [60] summarized and discussed how the food grouping systems of the various international food composition databases (FCDBs), in terms of number, type and class of consumed foods (e.g., ingredients, commercial products, cooked food, recipes, mixed dishes, etc.) vary between different countries (usually, 10 and 25 food groups), and are constantly evolving according to their changes and updates; the authors marked how these groupings are structured according to the convenience of using the nutritional composition of specific foods and, therefore, there is not an internationally standardized approach.

\section{Distribution of Lignans in Food: Occurrence}

Lignans are in a wide variety of plants from different origins, including the major edible plants. Amongst the latter, flaxseed and sesame seeds represent rich sources of lignans [40,61-65], whereas wood knots in coniferous trees, particularly Norway spruce, are identified as the most concentrated lignan sources known so far [66].

The main sources of dietary lignans are oilseeds (i.e., flax, soy, rapeseed, and sesame), whole-grain cereals (i.e., wheat, oats, rye, and barley), legumes, various vegetables and fruit (particularly berries), as well as beverages, such as coffee, tea, and wine, and, recently, lignans are also reported in dairy products, meat, and fish $[64,65,67-84]$. The types and amounts vary from one source to another. The content of some lignans, as well as the degree of esterification of their glycosides, could vary with different growing conditions, geographic location, climate, and genetic characteristics. Some examples of profile and distribution of lignans in common food groups are here reported, 
from research in the literature applying different methodological approaches. As concluded by Durazzo et al. [17], in a systematized assessment of lignans in cereals and cereal-based products for grains studied in $[65,73,76]$, the total average values in grains ranged between 23 and $401 \mu \mathrm{g} / 100 \mathrm{~g}$ dry weight, with lariciresinol the most representative. As, for instance, for vegetables, Milder et al. [64] reported a content of total lignans (as the sum of secoisolariciresinol, matairesinol, lariciresinol, and pinoresinol, and expressed as $\mu \mathrm{g} / 100 \mathrm{~g}$ fresh edible weight) of 1325 for broccoli, 185 for cauliflower, 787 for white cabbage, 171 for carrot, 58 for tomato, and 48 for chicory. Another example was given by Penalvo et al. [65] that described, for asparagus, a following profile of lignan concentrations: secoisolariciresinol $183 \mu \mathrm{g} / 100 \mathrm{~g}$ wet basis, syringaresinol $58 \mu \mathrm{g} / 100 \mathrm{~g}$ wet basis, pinoresinol $49 \mu \mathrm{g} / 100 \mathrm{~g}$ wet basis, lariciresinol $47 \mu \mathrm{g} / 100 \mathrm{~g}$ wet basis, medioresinol $5 \mu \mathrm{g} / 100 \mathrm{~g}$ wet basis, matairesinol $2 \mu \mathrm{g} / 100 \mathrm{~g}$ wet basis whereas, for eggplant, tomato, and radish, the most representative was lariciresinol [65]. For the fruit group, as reported in a work of Kuhnle [75] secoisolariciresinol and matairesinol were identified, respectively, in orange (peel and pith removed, 21 and $<1 \mu \mathrm{g} / 100 \mathrm{~g}$ wet weight), nectarine (stoned, 24 and $<1 \mu \mathrm{g} / 100 \mathrm{~g}$ wet weight), apricot (stoned, 51 and $<1 \mu \mathrm{g} / 100 \mathrm{~g}$ wet weight), mango (skinned and stoned, 17 and $1 \mu \mathrm{g} / 100 \mathrm{~g}$ wet weight), melon (cantaloupe, skin and seeds removed, 16 and $<1 \mu \mathrm{g} / 100 \mathrm{~g}$ wet weight), and others [75]. Moreover, Penalvo et al. [70] showed for avocado, a profile of decreasing concentration of lignans, syringaresinol $>$ pinoresinol $>$ medioresinol $>$ secoisolariciresinol $>$ lariciresinol $>$ matairesinol and for pineapple, syringaresinol $>$ lariciresinol $>$ matairesinol $>$ secoisolariciresinol $>$ pinoresinol $>$ medioresinol, whereas, the most representative lignan for navel orange was lariciresinol, and secoisolariciresinol for kiwifruit. In berries, as reported by Smeds et al. [78], the most representative lignans among those studied were lariciresinol for cloudberries (5008 $\mu \mathrm{g} / 100 \mathrm{~g}$ dry weight); secoisolariciresinol for blackberries $(2902 \mu \mathrm{g} / 100 \mathrm{~g}$ dry weight), lingoberries (2319 $\mathrm{g} / 100 \mathrm{~g}$ dry weight), blackcurrants (446 $\mu \mathrm{g} / 100 \mathrm{~g}$ dry weight); syringaresinol for cranberries $(2578 \mu \mathrm{g} / 100 \mathrm{~g}$ dry weight), sea buckthorns $(1177 \mu \mathrm{g} / 100 \mathrm{~g}$ dry weight), bilberries ( $801 \mu \mathrm{g} / 100 \mathrm{~g}$ dry weight), and red gooseberries (498 $\mu \mathrm{g} / 100 \mathrm{~g}$ dry weight); and pinoresinol for strawberries (1403 $\mu \mathrm{g} / 100 \mathrm{~g}$ dry weight); for raspberries the most representatives were lariciresinol (406 $\mu \mathrm{g} / 100 \mathrm{~g}$ dry weight), syringaresinol (388 $\mu \mathrm{g} / 100 \mathrm{~g}$ dry weight) and pinoresinol (377 $\mu \mathrm{g} / 100 \mathrm{~g}$ dry weight).

Within the beverage group, a recent work of Angeloni et al. [84] reported, for coffee samples from different Countries, secoisolariciresinol from 27.9 to $52.0 \mu \mathrm{g} \mathrm{L}{ }^{-1}$ and lariciresinol from 5.3 to $27.8 \mu \mathrm{g}$ $\mathrm{L}^{-1}$ respectively, contrary to matairesinol, that was not possible to detect it in each type of coffee.

For foods of animal origin, Kuhnle et al. [72] reported the content of lignans for the first time; in milk and its derived products, the content of dietary lignans was reported (as the sum of secoisolariciresinol, matairesinol, and shonanin) as follows: about $1 \mu \mathrm{g} / 100 \mathrm{~g}$ wet weight for skimmed, semi-skimmed, or whole milk; in the cheese group, from $<1 \mu \mathrm{g} / 100 \mathrm{~g}$ wet weight for feta cheese derived from ewe's and goat's milk, to $4 \mu \mathrm{g} / 100 \mathrm{~g}$ wet weight for mascarpone, $5 \mu \mathrm{g} / 100 \mathrm{~g}$ wet weight for parmesan, $6 \mu \mathrm{g} / 100 \mathrm{~g}$ wet weight for mozzarella (derived from buffalo milk), $13 \mu \mathrm{g} / 100 \mathrm{~g}$ wet weight for soft Philadelphia cheese (full fat), and to $25 \mu \mathrm{g} / 100 \mathrm{~g}$ wet weight for Wensleydale cheese. Moreover, cow milk, also condensed and evaporated, showed a content of enterolactone in a range of 3-9 $\mu \mathrm{g} / 100 \mathrm{~g}$ wet weight, and cheese in a range of 3-23 $\mu \mathrm{g} / 100 \mathrm{~g}$ wet weight.

The same authors [72] reported a dietary lignan content for meat (including different meat cuts and offal) at various cooking of 1-2 $\mu \mathrm{g} / 100 \mathrm{~g}$ wet weight in chicken, 3-9 $\mu \mathrm{g} / 100 \mathrm{~g}$ wet weight in pork, 4-16 $\mu \mathrm{g} / 100 \mathrm{~g}$ wet weight in beef, 4-17 $\mu \mathrm{g} / 100 \mathrm{~g}$ wet weight in lamb; whereas, for eggs, $2-3 \mu \mathrm{g} / 100 \mathrm{~g}$ wet weight for egg whites and 6-10 $\mathrm{gg} / 100 \mathrm{~g}$ wet weight for egg yolks. Small quantities of enterolignans $(<6 \mu \mathrm{g} / 100 \mathrm{~g}$ wet weight) were detected in some type of eggs and meat cuts.

Most of the foods are consumed after cooking or processing, depending on the type of food matrices and the eating habits of the consumers, indeed, researches are moving in this direction $[72,85,86]$; indeed, the evaluation of the effects of all type of factors on lignan content in different food matrices increase the reliability of lignan intake estimations. 
At the same time, procedures to improve the content of lignans such as milling, parboiling, or supplementation diet in animals [86-88] were optimized.

Nowadays, attention is paid to less common species and agro-industrial side streams [89-91], in order to continually explore new sources of lignans.

\section{Lignans and Databases: The Current Workflow}

Studies that examine the relationship between diet and health have led to increased interest in all biologically active constituents that are present together with nutrients in food, and data on these, as well as other compounds, are increasingly required in the database system.

A complete and comprehensive harmonized databases on the content of lignans in foods are useful in dietary assessment and in the evaluation of formulated diet, in order to be used in observational studies as key elements for healthy nutritional patterns [92]. Knowledge of the dietary intake of lignans is needed for understanding the relationship between a lignan-rich diet and the potential lower risk of development of various diseases, that is, hormone-related cancers, heart diseases, menopausal symptoms, and osteoporosis.

Detailed and accurate information on the lignans in foods is crucial in determining exposure and to investigate health effects in vivo.

To reach this objective, limitations were given by numerous existing factors-from one side, the diversity of the chemical features of compounds, the great number of dietary sources, and the large variability in content from a specified source, to the other side, the different extraction procedures and analytical techniques and methodologies [93]. Additional factors, in some cases, are given by the fact that several studies have been focused only on few compounds within a class, and by the lack of appropriate analytical methods.

In the last decade, researchers are addressing the identification and determination of lignan profiles in main food groups and in food chain products; when a new dataset for nutritional values is used, it is very important to evaluate the quality of the analytical information [55]. New experimental and analytical data on lignan content are now available for updating and expanding food composition databases [64,65,67-84]. In Table 1 the main national databases of lignans are described.

Table 1. National databases of lignans.

\begin{tabular}{|c|c|c|c|c|c|}
\hline Country & $\begin{array}{c}\text { Type of } \\
\text { Database }\end{array}$ & $\begin{array}{l}\text { Main/Common } \\
\text { Lignan } \\
\text { Compounds }\end{array}$ & $\begin{array}{l}\mathbf{N}^{\circ} \text { Total } \\
\text { Foods }\end{array}$ & $\begin{array}{l}\text { Food Groups and } \\
\text { Subgroups }\end{array}$ & References \\
\hline Finland & $\begin{array}{l}\text { Phytoestrogen } \\
\text { Database } \\
\text { including lignans }\end{array}$ & $\begin{array}{l}\text { Secoisolariciresinol } \\
\text { Matairesinol }\end{array}$ & 180 & $\begin{array}{c}\text { Vegetables, } \\
\text { Herbs and spices, } \\
\text { Mushrooms, } \\
\text { Fruits, } \\
\text { Miscellaneous }\end{array}$ & [67] \\
\hline Netherland & Lignan Database & $\begin{array}{c}\text { Secoisolariciresinol } \\
\text { Matairesinol } \\
\text { Lariciresinol } \\
\text { Pinoresinol }\end{array}$ & 109 & $\begin{array}{c}\text { Oilseeds and nuts, } \\
\text { Grain products, } \\
\text { Vegetables and } \\
\text { legumes, } \\
\text { Fruits, } \\
\text { Vegetable oils and fats, } \\
\text { Other solid foods, } \\
\text { Alcoholic beverages, } \\
\text { Non-alcoholic } \\
\text { beverages, } \\
\text { Juices, } \\
\text { Other beverages, }\end{array}$ & [64] \\
\hline
\end{tabular}


Table 1. Cont.

\begin{tabular}{|c|c|c|c|c|c|}
\hline Country & $\begin{array}{c}\text { Type of } \\
\text { Database }\end{array}$ & $\begin{array}{l}\text { Main/Common } \\
\text { Lignan } \\
\text { Compounds }\end{array}$ & $\begin{array}{l}\mathrm{N}^{\circ} \text { Total } \\
\text { Foods }\end{array}$ & $\begin{array}{l}\text { Food Groups and } \\
\text { Subgroups }\end{array}$ & References \\
\hline Canada & $\begin{array}{c}\text { Phytoestrogen } \\
\text { Database } \\
\text { including lignans }\end{array}$ & $\begin{array}{c}\text { Secoisolariciresinol } \\
\text { Matairesinol } \\
\text { Lariciresinol } \\
\text { Pinoresinol }\end{array}$ & 121 & $\begin{array}{c}\text { Soy products. } \\
\text { Legumes. } \\
\text { Nuts and oil seeds. } \\
\text { Vegetables. } \\
\text { Fruits. } \\
\text { Cereals and bread. } \\
\text { Meat products and } \\
\text { other processed foods. } \\
\text { Non-alcoholic } \\
\text { beverages. } \\
\text { Alcoholic beverages }\end{array}$ & [69] \\
\hline Japan & Lignan Database & $\begin{array}{c}\text { Secoisolariciresinol } \\
\text { Matairesinol } \\
\text { Lariciresinol } \\
\text { Pinoresinol } \\
\text { Syringaresinol } \\
\text { Medioresinol }\end{array}$ & 86 & $\begin{array}{c}\text { Vegetables. } \\
\text { Tubers and roots. } \\
\text { Mushrooms. } \\
\text { Fruits. } \\
\text { Legumes. } \\
\text { Soybean-based } \\
\text { products. } \\
\text { Cereal-based } \\
\text { products. } \\
\text { Animal-derived } \\
\text { products }\end{array}$ & [70] \\
\hline Spain & $\begin{array}{c}\text { Alkylresorcinols } \\
\text { and Lignans } \\
\text { Database }\end{array}$ & $\begin{array}{c}\text { Secoisolariciresinol } \\
\text { Matairesinol } \\
\text { Lariciresinol } \\
\text { Pinoresinol } \\
\text { Syringaresinol } \\
\text { Medioresinol }\end{array}$ & 593 & $\begin{array}{l}\text { Vegetables. } \\
\text { Grains. } \\
\text { Animal. } \\
\text { Fats. } \\
\text { Drinks }\end{array}$ & [77] \\
\hline $\begin{array}{l}\text { United } \\
\text { Kingdom }\end{array}$ & $\begin{array}{l}\text { Phytoestrogen } \\
\text { Database } \\
\text { including lignans }\end{array}$ & $\begin{array}{c}\text { Secoisolariciresinol } \\
\text { Matairesinol } \\
\text { (and Shonanin) }\end{array}$ & 496 & $\begin{array}{c}\text { Cereal and } \\
\text { cereal-based foods, } \\
\text { Fresh and processed } \\
\text { fruit } \\
\text { and vegetables } \\
\text { including soya-based } \\
\text { foods and legumes, } \\
\text { Nuts and seeds, } \\
\text { Oils. } \\
\text { Alcoholic beverages. } \\
\text { Tea and coffee. } \\
\text { Dairy products, } \\
\text { Eggs, } \\
\text { Meat, } \\
\text { Fish and seafood }\end{array}$ & {$[71,72,74,75]$} \\
\hline
\end{tabular}

The first examples of databases including lignans were movements toward the development of phytoestrogen databases [67,94]. Valsta et al. [67] reported on expansion of the Finnish National Food Composition Database (Fineli ${ }^{\circledR}$ ), compiling values for plant lignans, matairesinol, and secoisolariciresinol (shown in Figure 1), and the isoflavones, daidzein and genistein.

Further, Milder et al. [64] developed a lignan database for 83 solid foods and 26 beverages commonly consumed in the Netherlands: the amount of lignans in plant foods varied widely, from 0 to $301,129 \mu \mathrm{g} / 100 \mathrm{~g}$ fresh weight; in detail, the lignan values varied from 10 to $30,129 \mu \mathrm{g} / 100 \mathrm{~g}$ fresh edible weight of oilseeds and nuts, from 7 to $12,474 \mu \mathrm{g} / 100 \mathrm{~g}$ fresh edible weight of grain products, from 0 to $2321 \mu \mathrm{g} / 100 \mathrm{~g}$ fresh edible weight of vegetables, from 0 to $450 \mu \mathrm{g} / 100 \mathrm{~g}$ fresh edible weight of fruits, from 26 to $37 \mu \mathrm{g} / 100 \mathrm{~g}$ fresh edible weight of legumes, and in beverages ranged from 0 to $91 \mu \mathrm{g} / 100 \mathrm{~mL}$. Only five of the studied foods did not contain a measurable amount of lignans and, 
in most cases, the amount of lariciresinol and pinoresinol was larger than that of secoisolariciresinol and matairesinol.

On the basis of above mentioned lignan databases, in another work, Milder et al. [68] have assessed the lignan intake in a representative sample of 4660 Dutch adults (Dutch Food Consumption Survey, carried out in 1997-1998), reporting the following contribution percentages to lignan intake: lariciresinol and pinoresinol contributed 75\%, whereas secoisolariciresinol and matairesinol contributed $25 \%$; and the major food sources of lignans were beverages (37\%), followed by vegetables $(24 \%)$, nuts and seeds (14\%), bread (9\%), and fruits (7\%) [68].

Thompson et al. [69] developed a lignan database of foods consumed in Canada: nine phytoestrogens were identified in 121 food products of Canada by GC-MS, including lignans; decreasing amounts (on wet weight, $\mu \mathrm{g}$ per $100 \mathrm{~g}$ ) of total lignans are reported in the following order: nuts and oilseeds (25-379012), cereals and breads (2.0-7239.3), legumes (1.8-979.4), fruits (0.3-61.8), vegetables (1.2-583.2), soy products (2.2-269.2), meat products and other processed foods (0.2-415.1), alcoholic beverages (1.1-37.3), and non-alcoholic beverages (0.9-12). Matairesinol was the least-concentrated lignan in most studied foods, whereas secoisolariciresinol reached the highest concentration in 63 foods, lariciresinol in 44 foods, and pinoresinol in 14 foods [69].

Peñalvo et al. [70] have reported the content of six plant lignans (shown in Figure 1) in 86 food items commonly consumed in Japan: the amount of plant lignans ranged from 0 to $1724 \mu \mathrm{g} / 100 \mathrm{~g}$ (wet basis); in details, as for instance, considering the food group of vegetables, most of the lignans were in the stems and leaves of Japanese parsley, asparagus, Japanese spinach, bitter oranges, and Chinese citrus, and related concentrations in vegetables ranged from 19 to $1724 \mu \mathrm{g} / 100 \mathrm{~g}$ wet basis.

Moreno-Franco et al. [77] have developed the Aligna databases, by collecting data from scientific publications for alkylresorcinols and lignans in common foods and beverages, and by analyzing foods particularly consumed in Spain; moreover, the assess of lignans intake in Spain was evaluated and reported as follows: $0.76 \mathrm{mg} /$ day, with the major contributors, i.e. oils and fats (33 percent), fruits and vegetables (30 percent), bread (14 percent), and wine and beer (10 percent) [77].

In several works, Kuhnle et al. [71,72,74,75] reported the content of secoisolariciresinol and matairesinol in 115 foods of animal origin, 240 different foods based on fresh and processed fruit and vegetables, 101 cereal and cereal-based foods including bread, breakfast cereals, biscuits, pasta, and rice, and about 40 beverages, nuts, seeds, and oils. The study of Mulligan et al. [81] estimates the average intakes of isoflavones, lignans, enterolignans, and coumestrol in the Norfolk arm of the European Prospective Investigation into Cancer and Nutrition (EPIC-Norfolk) from 7-days food diaries, and provides data on total isoflavone, lignan, and phytoestrogen consumption by food group-the mean daily total lignan intake was 361 (SD 230) $\mu \mathrm{g}$ in soya-consuming men, and 311 (SD 178) $\mu \mathrm{g}$ in non-soya-consuming men; the mean daily total lignans intake was 318 (SD 212) $\mu \mathrm{g}$ in soya-consuming women and 251 (SD 141) $\mu \mathrm{g}$ in non-soya-consuming women [81].

It is worth mentioning the work of Tetens et al. [95] which estimated and evaluated the scale of consumption and the main food sources of lignans in five European countries using the Finnish databases [67], including lignans and Dutch lignan databases [64], respectively; in detail, 42 food groups known to contribute to the total lignan intake were selected and a value attributed for secoisolariciresinol and matairesinol from the Finnish lignan database (Fineli ${ }^{\circledR}$ ) or for secoisolariciresinol, matairesinol, lariciresinol, and pinoresinol from the Dutch database. The total intake of lignans was estimated from food consumption data for adult men and women (19-79 years) from Denmark, Finland, Italy, Sweden, United Kingdom, and the contribution of aggregated food groups calculated using the Dutch lignan database [75]. The authors showed that, compared to the total lignan intakes among Dutch men and women, the total lignan intakes were higher in Denmark and Sweden, and within similar range in Finland, Italy, and United Kingdom [75].

Here, also, are some examples of utilization of lignan databases to investigate the association between lignan intake and prevention of some chronic pathologies. 
A recent study was undertaken by Witkowska et al. [96] that examined the total and individual lignan intakes and their dietary sources in postmenopausal Polish women: for lignan content, the Dutch lignan database was used [64]; for beverages, nuts, seeds, and oils, data from Kuhnle et al. [71] were taken, and when data on lignan content were missing, values were taken from Thompson et al. [69]; in women with cardiovascular disease (CVD), secoisolariciresinol accounted for 50.15\% lignan intake from plant foods, as compared to $44.8 \%$ in the control. Pinoresinol, lariciresinol, and matairesinol contributed to the total lignan intakes of CVD and non-CVD women in $24.0 \%$ vs. $26.1 \%, 22.7 \%$ vs. $26.1 \%$, and $3.1 \%$ vs. $2.9 \%$, respectively [96].

Nowadays, the major core public databases that gather extensive data on the polyphenol content of foods and beverages include lignans-Phenol-Explorer [97], the first comprehensive database on polyphenol content in foods [98] and eBASIS (Bioactive Substances in Food Information Systems) [99-101], published through the EuroFIR project.

Phenol-Explorer was the first comprehensive web-based database on polyphenol content in foods and an open-access database and, now, throughout several updates [102,103], includes new data on pharmacokinetic and metabolites, the effect of food processing and cooking and, in the last update (version 3.6), 1451 new content values for lignans have been added (to the database). The development of the Phenol-Explorer database included five main steps: literature search, data compilation, data evaluation, data aggregation, and final data exportation to the MySQL database which is used by the web interface. Composition data were collected from peer-reviewed scientific publications, and evaluated before they were aggregated to produce final representative mean content values.

The eBASIS database contains composition data and biological effects of over 300 major European plant foods of 24 compound classes, such as glucosinolates, phytosterols, polyphenols, isoflavones, glycoalkaloids, and xanthine alkaloids in 15 EU languages. EuroFIR eBASIS resource is a compilation of expert critically evaluated data extracted from peer-reviewed literature as raw data. This could be seen and considered as the first effort to establish a harmonized food composition information system in EU. Indeed, eBASIS should be defined as the first EU harmonized food composition database. Currently, 2695 data points for lignans were inserted in eBASIS, in detail, 658 values for secoisolariciresinol, 550 values for matairesinol, 313 values for lariciresinol, 276 values for pinoresinol, 93 values for medioresinol, and 86 values for syringaresinol $[99,101]$.

Indeed, considering the importance of metabolic pathways and the benefits of bioactive compounds in humans, it is worth mentioning the Human Metabolome Database or HMDB 4.0 [104], a web metabolomic database on human metabolites including lignans and their metabolites [105], as well as PhytoHub [106], a freely electronic database containing detailed information about all phytochemicals and their metabolites commonly ingested in diets [107].

Author Contributions: A.D., M.L., A.S. and L.M. have conceived the work and wrote the manuscript. All authors have made a substantial contribution to revise the work, and approved it for publication.

Funding: This research did not receive any specific grant from funding agencies in the public, commercial, or not-profit sectors.

Conflicts of Interest: The authors declare no conflict of interest.

\section{References}

1. Durazzo, A. Lignans. In Phenolic Compounds in Food: Characterization and Analysis (Food Analysis and Properties); Leo, M.L.N., Janet, A.G.-U., Eds.; CRC Press: Boca Raton, FL, USA, 2018; Chapter 11.

2. Lewis, N.G.; Davin, L.B. Lignans: Biosynthesis and function. In Comprehensive Natural Products Chemistry; Barton, D., Nakanishi, K., Meth-Cohn, O., Eds.; Elsevier: Amsterdam, the Netherlands, 1999; pp. 639-712.

3. Imai, T.; Nomura, M.; Fukushima, K. Evidence for involvement of the phenylpropanoid pathway in the biosynthesis of the norlignan agatharesinol. J. Plant Physiol. 2006, 163, 483-487. [CrossRef] [PubMed]

4. Pan, J.-Y.; Chen, S.-L.; Yang, M.-H.; Wu, J.; Sinkkonen, J.; Zou, K. An update on lignans: Natural products and synthesis. Nat. Prod. Rep. 2009, 26, 1251-1292. [CrossRef] [PubMed] 
5. Teponno, R.B.; Kusari, S.; Spiteller, M. Recent advances in research on lignans and neolignans. Nat. Prod. Rep. 2016, 33, 1044-1092. [CrossRef] [PubMed]

6. Huang, X.Y.; Feng, Z.M.; Yang, Y.N.; Jiang, J.S.; Zhang, P.C. Four new neolignan glucosides from the fruits of Arctium lappa. J. Asian Nat. Prod. Res. 2015, 17, 504-511. [CrossRef] [PubMed]

7. Duarte, S.L.F.; Nascimento, Y.M.; Madeiro, S.A.L.; Costa, V.C.O.; Agra, M.F.A.; Sobrala, M.V.; Braz-Filho, R.; Carvalho, M.G.; Carvalho, J.E.; Ruiz, A.L.T.G.; et al. Luclaricin, a new lignan Phyllanthus acuminatus. Quim. Nova 2018, 41, 880-883. [CrossRef]

8. Mo, X.; Chen, Y.; Han, Y.; Hao, H.; Huang, R. A New Benzylbutane Lignan from the Stems of Schisandra bicolor. Chem. Nat. Comp. 2018, 54, 872-874. [CrossRef]

9. Gnabre, J.; Bates, R.; Huang, R.C. Creosote bush lignans for human disease treatment and prevention: Perspectives on combination therapy. J. Trad. Complem. Med. 2015, 5, 119-126. [CrossRef] [PubMed]

10. Su, S.; Wink, M. Natural lignans from Arctium lappa as antiaging agents in Caenorhabditis elegans. Phytochemistry 2015, 117, 340-350. [CrossRef] [PubMed]

11. Zhu, Y.; Huang, R.Z.; Wang, C.G.; Ouyang, X.L.; Jing, X.T.; Liang, D.; Wang, H.S. New inhibitors of matrix metalloproteinases 9 (MMP-9): Lignans from Selaginella moellendorffii. Fitoterapia 2018, 130, $281-289$. [CrossRef]

12. Landete, J.M. Plant and mammalian lignans: A review of source, intake, metabolism, intestinal bacteria and health. Food Res. Int. 2012, 46, 410-424. [CrossRef]

13. Saarinen, N.M.; Tuominen, J.; Pylkkänen, L.; Santti, R. Assessment of information to substantiate a health claim on the prevention of prostate cancer by lignans. Nutrients 2010, 2, 99-115. [CrossRef] [PubMed]

14. Velentzis, L.S.; Cantwell, M.M.; Cardwell, C.; Keshtgar, M.R.; Leathem, A.J.; Woodside, J.V. Lignans and breast cancer risk in pre- and post-menopausal women: Meta-analyses of observational studies. Br. J. Canc. 2009, 100, 1492-1498. [CrossRef] [PubMed]

15. Aehle, E.; Müller, U.; Eklund, P.C.; Willför, S.M.; Sippl, W.; Dräger, B. Lignans as food constituents with estrogen and antiestrogen activity. Phytochemistry 2011, 72, 2396-2405. [CrossRef] [PubMed]

16. Kiyama, R. Biological effects induced by estrogenic activity of lignans. Trends Food Sci. Technol. 2016, 54, 186-196. [CrossRef]

17. Durazzo, A.; Turfani, V.; Azzini, E.; Maiani, G.; Carcea, M. Phenols, lignans and antioxidant properties of legume and sweet chestnut flours. Food Chem. 2013, 140, 666-671. [CrossRef] [PubMed]

18. Muir, A.D. Flax lignans: New opportunities for functional foods. Food Sci. Technol. Bull. 2010, 6, 61-79. [CrossRef]

19. Cunha, W.R.; e Silva, M.L.A.; Sola, R.C.; Veneziani, S.R.A.; Bastos, J.K. Lignans: Chemical and biological properties. In Phytochemicals-A global Perspective of Their Role in Nutrition and Health; Venketeshwer, R., Ed.; In Tech: Rijeka, Croatia, 2012; pp. 213-234.

20. Peterson, J.; Dwyer, J.; Adlercreutz, H.; Scalbert, A.; Jacques, P.; McCullough, M.L. Dietary lignans: Physiology and potential for cardiovascular disease risk reduction. Nutr. Rev. 2010, 68, 571-603. [CrossRef]

21. Peñalvo, J.L.; Lopez-Romero, P. Urinary enterolignan concentrations are positively associated with serum HDL cholesterol and negatively associated with serum triglycerides in U.S. adults. J. Nutr. 2012, 142, 751-756. [CrossRef]

22. Zamora-Ros, R.; Agudo, A.; Lujan-Barroso, L.; Isabelle, R.; Pietro, F.; Viktoria, K.; Bueno-de-Mesquita, H.B.; Max, L.; Ruth, C.T.; Carmen, N.; et al. Dietary flavonoid and lignan intake and gastric adenocarcinoma risk in the European Prospective Investigation into Cancer and Nutrition (EPIC) study. Am. J. Clin. Nutr. 2012, 96, 1398-1408. [CrossRef]

23. Zamora-Ros, R.; Touillaud, M.; Rothwell, J.A.; Romieu, I.; Scalbert, A. Measuring exposure to the polyphenol metabolome in observational epidemiologic studies: Current tools and applications and their limits. Am. J. Clin. Nutr. 2014, 100, 11-26. [CrossRef]

24. Durazzo, A.; Carcea, M.; Adlercreutz, H.; Azzini, E.; Polito, A.; Olivieri, L.; Zaccaria, M.; Meneghini, C.; Maiani, F.; Bausano, G.; et al. Effects of consumption of whole grain foods rich in lignans in healthy postmenopausal women with moderate serum cholesterol: A. pilot study. Int. J. Food Sci. Nutr. 2014, 65, 637-645. [CrossRef] [PubMed]

25. Sun, Q.; Wedick, N.M.; Pan, A.; Townsend, M.K.; Cassidy, K.; Franke, A.A.; Rimm, E.B.; Hu, F.B.; van Dam, R.B. Gut Microbiota Metabolites of Dietary Lignans and Risk of Type 2 Diabetes: A Prospective Investigation in Two Cohorts of U.S. Women. Diabetes Care 2014, 37, 1287-1295. [CrossRef] [PubMed] 
26. Chang, V.C.; Cotterchio, M.; Boucher, B.A.; Jenkins, D.J.A.; Mirea, L.; McCann, S.E.; Thompson, L.U. Effect of Dietary Flaxseed Intake on Circulating Sex Hormone Levels among Postmenopausal Women: A Randomized Controlled Intervention Trial. Nutr. Cancer. 2018, 30, 1-14. [CrossRef] [PubMed]

27. Barre, D.E.; Mizier-Barre, K.A. Lignans' potential in pre- and post-onset type 2 diabetes management. Curr. Diabetes Rev. 2018, in press. [CrossRef] [PubMed]

28. Santini, A.; Novellino, E.; Armini, V.; Ritieni, A. State of the art of Ready-to-Use Therapeutic Food: A tool for nutraceuticals addition to foodstuff. Food Chem. 2013, 140, 843-849. [CrossRef] [PubMed]

29. Santini, A.; Tenore, G.C.; Novellino, E. Nutraceuticals: A paradigm of proactive medicine. Eur. J. Pharm. Sci. 2017, 96, 53-61. [CrossRef]

30. Adefegha, S.A. Functional foods and nutraceuticals as dietary Intervention in chronic diseases; novel perspectives for health promotion and disease prevention. J. Diet. Suppl. 2018, 15, 977-1009. [CrossRef]

31. Durazzo, A.; D'Addezio, L.; Camilli, E.; Piccinelli, R.; Turrini, A.; Marletta, L.; Marconi, S.; Lucarini, M.; Lisciani, S.; Gabrielli, P.; et al. From plant compounds to botanicals and back: A current snapshot. Molecules 2018, 23, 1844. [CrossRef]

32. Santini, A.; Novellino, E. Nutraceuticals—shedding light on the grey area between pharmaceuticals and food. Expert. Rev. Clin. Pharmacol. 2018, 11, 545-547. [CrossRef]

33. Pilkington, L.I. Lignans: A Chemometric Analysis. Molecules 2018, 23, 1666. [CrossRef]

34. Obermeyer, W.R.; Musser, S.M.; Betz, J.M.; Casey, R.E.; Pohland, A.E.; Page, S.W. Chemical studies of phytoestrogens and related compounds in dietary supplements: Flax and chaparral. Proc. Soc. Exp. Biol. Med. 1995, 208, 6-12. [CrossRef]

35. Mazur, W.; Fotsis, T.; Wahala, K.; Ojala, S.; Salakka, A.; Adlercreutz, H. Isotope dilution gas chromatographic-mass spectrometric method for the determination of isoflavonoids, coumestrol, and lignans in food samples. Anal. Biochem. 1996, 233, 169-180. [CrossRef] [PubMed]

36. Nilsson, M.; Åman, P.; Härkönen, H.; Hallmans, G.; Knudsen, K.E.B.; Mazur, W.; Adlercreutz, H. Content of nutrients and lignans in roller milled fractions of rye. J. Sci. Food Agric. 1997, 73, 143-148. [CrossRef]

37. Meagher, L.P.; Beecher, G.R.; Flanagan, V.P.; Li, B.W. Isolation and characterization of the lignan, isolariciresinol and pinoresinol in flaxseed meal. J. Agric. Food Chem. 1999, 47, 3173-3180. [CrossRef] [PubMed]

38. Johnsson, P.; Kamal Eldin, A.; Lundgren, L.N.; Aman, P. HPLC method for analysis of secoisolariciresinol diglucoside in flaxseed. J. Agric. Food Chem. 2000, 48, 5216-5219. [CrossRef] [PubMed]

39. Kraushofer, T.; Sontag, G. Determination of matairesinol in flaxseed by HPLC with coulometric electrode array detection. J. Chrom. B 2002, 777, 61-66. [CrossRef]

40. Muir, A.D.; Westcott, N.D. Flaxseed constituents and human health. In Flax: The Genus Linum; Muir, A.D., Westcott, N.D., Eds.; Taylor \& Francis: London, UK, 2003; pp. 243-251.

41. Willför, S.M.; Smeds, A.I.; Holmbom, B.R. Chromatographic analysis of lignans. J. Chromatogr. A 2006, 1112, 64-77. [CrossRef]

42. Smeds, A.I.; Eklund, P.C.; Sjöholm, R.E.; Willför, S.M.; Nishibe, S.; Deyama, T.; Holmbom, B.R. Quantification of a broad spectrum of lignans in cereals, oilseeds, and nuts. J. Agric. Food Chem. 2007, 55, 1337-1346. [CrossRef]

43. Schwartz, H.; Sontag, G. Analysis of lignans in food samples-impact of sample preparation. Curr. Bioact. Compd. 2011, 7, 156-171. [CrossRef]

44. Nørskov, N.P.; Knudsen, K.E.B. Validated LC-MS/MS Method for the Quantification of free and bound lignans in cereal-based diets and feces. J. Agric. Food Chem. 2016, 64, 8343-8351. [CrossRef]

45. Hanhineva, K.; Rogachev, I.; Aura, A.M.; Aharoni, A.; Poutanen, K.; Mykkänen, H. Identification of novel lignans in the whole grain rye bran by non-targeted LC-MS metabolite profiling. Metabolomics 2012, 8 , 399-409. [CrossRef]

46. Linder, T.; Schnürch, M.; Mihovilovic, M.D. Construction of heterocyclic lignans in natural product synthesis and medicinal chemistry. In Targets in Heterocyclic Systems (Reviews and Accounts on Heterocyclic Chemistry); Attanasi, O.A., Merino, P., Spinelli, D., Eds.; Società Chimica Italiana: Rome, Italy, 2015; volume 19.

47. Soorukram, D.; Pohmakotr, M.; Kuhakarn, C.; Reutrakul, V. Stereoselective synthesis of tetrahydrofuran lignans. Synthesis 2018, in press. [CrossRef] 
48. Vo, Q.V.; Nam, P.C.; Bay, M.V.; Thong, N.M.; Cuong, N.D.; Mechler, A. Density functional theory study of the role of benzylic hydrogen atoms in the antioxidant properties of lignans. Sci. Rep. 2018, 8, 12361. [CrossRef] [PubMed]

49. Waltner-Towes, D.; Lang, T. A new conceptual base for food and agricultural policy: The emerging model of links between agriculture, food, health, environment and society. Glob. Chang. Hum. Health 2000, 1, 116-130. [CrossRef]

50. Astley, S.; Finglas, P. Nutrition and Health. Ref. Module Food Sci. 2016. Available online: https://doi.org/10. 1016/B978-0-08-100596-5.03425-9 (accessed on 7 May 2016).

51. World Health Organization, Food Safety. 2017. Available online: http://www.who.int/mediacentre/ factsheets/fs399/en/ (accessed on 31 October 2017).

52. Lampe, J.W.; Atkinson, C.; Hullar, M.A. Assessing exposure to lignans and their metabolites in humans. J. AOAC Int. 2006, 89, 1174-1181.

53. Encyclopaedia Britannica. Available online: https://www.britannica.com/technology/database (accessed on 20 November 2018).

54. Sofroniou, A. Relational Databases and Distributed Systems; lulu.com: Morrisville, CA, USA, 2018.

55. Greenfield, H.; Southgate, D.A.T. Food Composition Data. Production, Management, and Use, 2nd ed.; Food and Agriculture Organization of The United Nations: Rome, Italy, 2003.

56. Pakkala, H.; Christensen, T.; de Victoria, I.M.; Presser, K.; Kadvan, A. Harmonised information exchange between decentralised food composition database systems. Eur. J. Clin. Nutr. 2010, 64, S58-S63. [CrossRef] [PubMed]

57. Finglas, P.M.; Berry, R.; Astley, S. Assessing and improving the quality of food composition databases for nutrition and health applications in Europe: The contribution of EuroFIR. Adv. Nutr. 2014, 5, 608-614. [CrossRef]

58. Becker, W. CEN/TC387 Food Data. Towards a CEN Standard on food data. Eur. J. Clin. Nutr. 2010, 64, S49-S52. [CrossRef]

59. Finglas, P.; Roe, M.; Pinchen, H.; Astley, S. The contribution of food composition resources to nutrition science methodology. Nutr. Bull. 2017, 42, 198-206. [CrossRef]

60. Durazzo, A.; Camilli, E.; D’Addezio, L.; Le Donne, C.; Ferrari, M.; Marconi, S.; Marletta, L.; Mistura, L.; Piccinelli, R.; Scalvedi, M.L.; et al. Food Groups and Individual Foods: Nutritional Attributes and Dietary Importance. Ref. Module Food Sci. 2018, 1-13. [CrossRef]

61. Thompson, L.U.; Richard, S.E.; Cheung, F.; Kenaschuk, E.O.; Obermeyer, W.R. Variability in anticancer lignan levels in flaxseed. Nutr. Cancer 1997, 27, 26-30. [CrossRef] [PubMed]

62. Mazur, W.M.; Adlercreutz, H. Natural and anthropogenic environmental estrogens: The scientific basis for risk assessment; naturally occurring estrogens in food. Pure. Appl. Chem. 1998, 70, 1759-1776. [CrossRef]

63. Coulman, K.D.; Liu, Z.; Hum, W.Q.; Michaelides, J.; Thompson, L.U. Whole sesame seed is as rich a source of mammalian lignan precursors as whole flaxseed. Nutr. Cancer 2005, 52, 156-165. [CrossRef] [PubMed]

64. Milder, I.E.; Arts, I.C.; van de Putte, B.; Venema, D.P.; Hollman, P.C. Lignan contents of Dutch plant foods: A database including lariciresinol, pinoresinol, secoisolariciresinol and matairesinol. Brit. J. Nutr. 2005, 93, 393-402. [CrossRef] [PubMed]

65. Peñalvo, J.L.; Haajanen, K.M.; Botting, N.; Adlercreutz, H. Quantification of lignans in food using isotope dilution gas chromatography/mass spectrometry. J. Agric. Food Chem. 2005, 53, 9342-9347. [CrossRef] [PubMed]

66. Holmbom, B.; Eckerman, C.; Eklund, P.; Hemming, J.; Nisula, L.; Reunanen, M.; Sjöholm, R.; Sundberg, A.; Sundberg, K.; Willför, S. Knots in trees-A new rich source of lignans. Phytochem. Rev. 2003, 2, 331-340. [CrossRef]

67. Valsta, L.M.; Kilkkinen, A.; Mazur, W.; Nurmi, T.; Lampi, A.M.; Ovaskainen, M.L.; Korhonen, T.; Adlercreutz, H.; Pietinen, P. Phyto-oestrogen database of foods and average intake in Finland. Br. J. Nutr. 2003, 89, S31-S38. [CrossRef]

68. Milder, I.E.J.; Feskens, E.J.M.; Arts, I.C.W.; Bueno-de-Mesquita, H.B.; Hollman, P.C.H.; Kromhout, D. Intake of the plant lignans secoisolariciresinol, matairesinol, lariciresinol and pinoresinol in Dutch men and women. J. Nutr. 2005, 135, 1202-1207. [CrossRef]

69. Thompson, L.U.; Boucher, B.A.; Liu, Z.; Cotterchio, M.; Kreiger, N. Phytoestrogen content of foods consumed in Canada, including isoflavones, lignans and coumestan. Nutr. Cancer 2006, 54, 184-201. [CrossRef] 
70. Peñalvo, J.L.; Adlercreutz, H.; Uehara, M.; Ristimaki, A.; Watanabe, S. Lignan content of selected foods from Japan. J. Agric. Food Chem. 2008, 56, 401-409. [CrossRef]

71. Kuhnle, G.G.C.; Dell'Aquila, C.; Aspinall, S.M.; Runswick, S.A.; Mulligan, A.A.; Bingham, S.A. Phytoestrogen content of beverages, nuts, seeds, and oils. J. Agric. Food Chem. 2008, 56, 7311-7315. [CrossRef] [PubMed]

72. Kuhnle, G.G.C.; Dell'Aquila, C.; Aspinall, S.M.; Runswick, S.A.; Mullingan, A.A.; Bingham, S.A. Phytoestrogen content of foods of animal origin: Dairy products, eggs, meat, fish, and seafood. J. Agric. Food Chem. 2008, 56, 10099-10104. [CrossRef] [PubMed]

73. Durazzo, A.; Raguzzini, A.; Azzini, E.; Foddai, M.S.; Narducci, V.; Maiani, G.; Carcea, M. Bioactive molecules in cereals. Tecnica Molitoria Int. 2009, 60, 150-162.

74. 68Kuhnle, G.G.C.; Dell'Aquila, C.; Aspinall, S.M.; Runswick, S.A.; Mulligan, A.A.; Bingham, S.A. Phytoestrogen content of cereals and cereal based foods consumed in the UK. Nutr. Cancer 2009, 61, 302-309.

75. Kuhnle, G.G.C.; Dell'Aquila, C.; Sue, M.A.; Runswick, S.A.; Joosen, A.M.C.P.; Mulligan, A.A.; Bingham, S.A. Phytoestrogen content of fruits and vegetables commonly consumed in the UK based on LC-MS and 13C-labelled standards. Food Chem. 2009, 116, 542-554. [CrossRef]

76. Smeds, A.I.; Jauhiainen, L.; Tuomola, E.; Peltonen-Sainio, P. Characterization of variation in the lignan content and composition of winter rye, spring wheat and spring oat. J. Agric. Food Chem. 2009, 57, 5837-5842. [CrossRef] [PubMed]

77. Moreno-Franco, B.; Garcia-Gonzalez, A.; Montero-Bravo, A.M.; Iglesias-Gitierrez, E.; Ubeda, N.; Maroto-Nunez, L.; Adlercreutz, H.; Penãlvo, J. Dietary alkylresorcinols and lignans in the Spanish diet: Development of the Alignia database. J. Agric. Food Chem. 2011, 59, 9827-9834. [CrossRef]

78. Smeds, A.I.; Eklund, P.C.; Willför, S.M. Content, composition, and stereochemical characterisation of lignans in berries and seeds. Food Chem. 2012, 134, 1991-1998. [CrossRef]

79. Durazzo, A.; Azzini, E.; Turfani, V.; Polito, A.; Maiani, G.; Carcea, M. Effect of cooking on lignans content in wholegrain pasta made with different cereals and other seeds. Cereal Chem. 2013, 90, 169-171. [CrossRef]

80. Durazzo, A.; Zaccaria, M.; Polito, A.; Maiani, G.; Carcea, M. Lignan content in cereals, buckwheat and derived foods. Foods 2013, 2, 53-63. [CrossRef]

81. Mulligan, A.A.; Kuhnle, G.G.; Lentjes, M.A.; van Scheltinga, V.; Powell, N.A.; McTaggart, A.; Bhaniani, A.; Khaw, K.T. Intakes and sources of isoflavones, lignans, enterolignans, coumestrol and soya-containing foods in the Norfolk arm of the European Prospective Investigation into Cancer and Nutrition (EPIC-Norfolk), from $7 \mathrm{~d}$ food diaries, using a newly updated database. Public Health Nutr. 2013, 16, 1454-1462. [CrossRef] [PubMed]

82. Durazzo, A.; Turfani, V.; Narducci, V.; Azzini, E.; Maiani, G.; Carcea, M. Nutritional characterization and bioactive components of commercial carobs flours. Food Chem. 2014, 153, 109-113. [CrossRef] [PubMed]

83. Turfani, V.; Narducci, V.; Durazzo, A.; Galli, V.; Carcea, M. Technological, nutritional and functional properties of wheat bread enriched with lentil or carob flours. LWT Food Sci. Technol. 2017, 78, 361-366. [CrossRef]

84. Angeloni, A.; Navarini, L.; Sagratini, L.; Torregiani, E.; Vittori, S.; Caprioli, G. Development of an extraction method for the quantification of lignans in espresso coffee by using HPLC-MS/MS triple quadrupole. J. Mass Spectrom. 2018, 53, 842-848. [CrossRef] [PubMed]

85. Gerstenmeyer, E.; Reimer, S.; Berghofer, E.; Schwartz, H.; Sontag, G. Effect of thermal heating on some lignans in flax seed, sesame seeds and rye. Food Chem. 2013, 138, 1847-1855. [CrossRef] [PubMed]

86. Pihlava, J.M.; Nordlund, E.; Heinio, R.L.; Hietaniemi, V.; Lehtinen, P.; Poutanen, K. Phenolic compounds in wholegrain rye and its fractions. J. Food Comp. Anal. 2015, 38, 89-97. [CrossRef]

87. Durazzo, A.; Azzini, E.; Raguzzini, A.; Maiani, G.; Finocchiaro, F.; Ferrari, B.; Gianinetti, A.; Carcea, M. Influence of processing on the lignans content of cereal based foods. Tecnica Molitoria Int. 2009, 60, 163-173.

88. Mattioli, S.; Ruggeri, S.; Sebastiani, B.; Brecchia, G.; Dal Bosco, A.; Mancinelli, A.C.; Castellini, C. Performance and egg quality of laying hens fed flaxseed: Highlights on n-3 fatty acids, cholesterol, lignans and isoflavones. Animal 2017, 11, 705-712. [CrossRef]

89. Inostroza, J.P.; Troncoso, J.; Mardones, C.; Vergara, C. Lignans in olive stones discarded from the oil industry. Comparison of three extraction Methods followed by HPLC-DAD-MS/MS and antioxidant capacity determination. J. Chil. Chem. Soc. 2018, 63, 4001-4005. [CrossRef]

90. Jablonský, M.; Škulcová, A.; Malvis, A.; Šima, J. Extraction of value-added components from food industry based and agro-forest biowastes by deep eutectic solvents. J. Biotechnol. 2018, 282, 46-66. [CrossRef] 
91. Lucarini, M.; Durazzo, A.; Romani, A.; Campo, M.; Lombardi-Boccia, G.; Cecchini, F. Bio-based vompounds from grape seeds: A biorefinery approach. Molecules 2018, 23, 1888. [CrossRef] [PubMed]

92. Blitz, C.L.; Murphy, S.P.; Au, D.L.M. Adding lignan values to a food composition database. J. Food Compos. Anal. 2007, 20, 99-105. [CrossRef]

93. Scalbert, A.; Andres-Lacueva, C.; Arita, M.; Kroon, P.; Manach, C.; Urpi-Sarda, M.; Wishart, D. Databases on food phytochemicals and their health-promoting effects. J. Agric. Food Chem. 2011, 59, 4331-4348. [CrossRef] [PubMed]

94. Horn-Ross, P.L.; Barnes, S.; Lee, M.; Coward, L.; Mandel, J.E.; Koo, J.; John, E.M.; Smith, M. Assessing phytoestrogen exposure in epidemiologic studies: Development of a database (United States). Cancer Causes Control. 2000, 11, 289-298. [CrossRef] [PubMed]

95. Tetens, I.; Turrini, A.; Tapanainen, H.; Christensen, T.; Lampe, J.W.; Fagt, S.; Hakansson, N.; Lundquist, A.; Hallund, J.; Valsta, L.M.; et al. Dietary intake and main sources of plant lignans in five European countries. Food Nutr. Res. 2013, 57, 1. [CrossRef] [PubMed]

96. Witkowska, A.M.; Waskiewicz, A.; Zujko, M.E.; Szczesniewska, D.; Stepaniak, U.; Pajak, A.; Drygas, W. Are total and individual dietary lignans related to cardiovascular disease and its risk factors in postmenopausal women? A. Nationwide Study. Nutrients 2018, 10, 865. [CrossRef] [PubMed]

97. Phenol-Explorer-Database on Polyphenol Content in Foods. Available online: http:/ / phenol-explorer.eu/ (accessed on 29 November 2018).

98. Neveu, V.; Perez-Jiménez, J.; Vos, F.; Crespy, V.; du Chaffaut, L.; Mennen, L.; Knox, C.; Eisner, R.; Cruz, J.; Wishart, D.; Scalbert, A. Phenol-Explorer: An online comprehensive database on polyphenol contents in foods. Database 2010, 2010, bap024. [CrossRef]

99. eBASIS-Bioactive Substances in Food Information System. Available online: http://ebasis.eurofir.org/ Default.asp (accessed on 29 October 2018).

100. Kiely, M.; Black, L.J.; Plumb, J.; Kroon, P.A.; Hollman, P.C.; Larsen, J.C.; Speijers, G.J.; Kapsokefalou, M.; Sheehan, D.; Gry, J.; et al. EuroFIR consortium. EuroFIR eBASIS: Application for health claims submissions and evaluations. Eur. J. Clin. Nutr. 2010, 3, S101. [CrossRef]

101. Plumb, J.; Pigat, S.; Bompola, F.; Cushen, M.; Pinchen, H.; Nørby, E.; Astley, S.; Lyons, J.; Kiely, M.; Finglas, P. eBASIS (Bioactive Substances in Food Information Systems) and Bioactive Intakes: Major Updates of the Bioactive Compound Composition and Beneficial Bioeffects Database and the Development of a Probabilistic Model to Assess Intakes in Europe. Nutrients 2017, 9, 320. [CrossRef]

102. Rothwell, J.A.; Urpi-Sarda, M.; Boto-Ordonez, M.; Knox, C.; Llorach, R.; Eisner, R.; Cruz, J.; Neveu, V.; Wishart, D.; Manach, C.; et al. Phenol-Explorer 2.0: A major update of the Phenol-Explorer database integrating data on polyphenol metabolism and pharmacokinetics in humans and experimental animals. Database 2012, 2012, bas031. [CrossRef]

103. Rothwell, J.A.; Perez-Jimenez, J.; Neveu, V.; Medina-Remon, A.; M'Hiri, N.; Garcia-Lobato, P.; Manach, C.; Knox, C.; Eisner, R.; Wishart, D.S.; et al. Phenol-Explorer 3.0: A major update of the Phenol-Explorer database to incorporate data on the effects of food processing on polyphenol content. Database 2013, 2013, bat070.

104. HMDB_Human Metabolome Database. Available online: www.hmdb.ca (accessed on 29 October 2018).

105. Wishart, D.S.; Feunang, Y.D.; Marcu, A.; Guo, A.C.; Liang, K.; Vázquez-Fresno, R.; Sajed, T.; Johnson, D.; Li, C.; Karu, N.; et al. HMDB 4.0-The Human Metabolome Database for 2018. Nucleic Acids Res. 2018, 46, D608-D617. [CrossRef] [PubMed]

106. PhytoHub Database. Available online: www.phytohub.eu (accessed on 8 June 2018).

107. Bento da Silva, A.; Giacomoni, F.; Pavot, B.; Fillâtre, Y.; Rothwell, J.A.; Sualdea, B.B.; Veyrat, C.; Garcia-Villalba, R.; Gladine, C.; Kopec, R.; et al. PhytoHub V1.4: A new release for the online database dedicated to food phytochemicals and their human metabolites. In Proceedings of the 1st International Conference on Food Bioactivities \& Health, Norwich, UK, 13-15 September 2016.

Sample Availability: Not available.

(c) 2018 by the authors. Licensee MDPI, Basel, Switzerland. This article is an open access article distributed under the terms and conditions of the Creative Commons Attribution (CC BY) license (http://creativecommons.org/licenses/by/4.0/). 